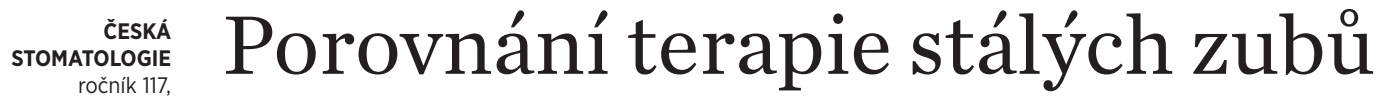 s nedokončeným vývojem a nekrotickou dření apexifikací hydroxidem vápenatým a maturogenezí
}

(Původní práce - klinická retrospektivní kohortová studie)

\section{Assessment of Therapy of Necrotic Immature Permanent Teeth with Calcium Hydroxide Apexification and Maturogenesis}

(Original Article - Clinical Retrospective Cohort Study)

\section{Žižka R.', Krejčí P.', Šedý J.2,3}

'Klinika zubního lékařství LF UP a FN, Olomouc

2Ústav normální anatomie LF UP, Olomouc

${ }^{3}$ Privátní stomatologická praxe, Praha

\section{SOUHRN}

Úvod a cíl práce: Endodontické ošetření stálých zubů s nedokončeným vývojem a nekrotickou dření patří $k$ nejnáročnějším výkonům $v$ endodoncii. $\vee$ posledních dvou dekádách byly popsány postupy, které využívají poznatků regenerativní medicíny a jejichž cílem je obnova pulpodentinového orgánu. Cílem naší studie bylo retrospektivně porovnat klinickou úspěšnost a rentgenologický prírůstek mineralizovaných tkání při ošetření apexifikací hydroxidem vápenatým - $\mathrm{Ca}(\mathrm{OH})_{2}$ a maturogenezí.

Metodika: Byly shromážděny záznamy pacientů do 16 let věku, kteři podstoupili endodontické ošetření stálého zubu s neukončeným vývojem a nekrotickou dření na Klinice zubního lékařství v Olomouci v období let 2011-2015. Z celkového počtu 54 pacientů bylo podle stanovených kritérií vybráno 17 pacientů, z čehož devět bylo ošetřeno apexifikací $\mathrm{Ca}(\mathrm{OH})$, a osm maturogenezí. $V$ rámci kontrol byly zhotoveny kontrolní RTG snímky a bylo provedeno klinické vyšetření. Následně byla provedena matematická korekce kontrolních snímků z poslední návštěvy a stanovila se procentuální změna radiologického povrchu kořene a procentuální změna radiologické délky kořene oproti původnímu stavu. Po vyhodnocení normality získaných dat Wilkovým-Shapirovým testem byly nulové hypotézy zkoumány Studentovým t-testem a jednovýběrovým a dvouvýběrovým Wilcoxonovým testem. Klinická úspěšnost byla testována Fisherovým faktoriálovým testem.

Výsledky: Při porovnání změn radiologického povrchu kořene byl pozorován signifikantní přírůstek hmoty ve prospěch maturogeneze, kde průměrná změna radiologického povrchu kořene je $16 \%$ $(p=0,0041)$ oproti apexifikaci $\mathrm{Ca}(\mathrm{OH})_{2}$, která je $5,9 \%$. Statisticky signifikantní rozdíly nebyly zjištěny ani ve změně mezi radiologickými délkami $(p=0,939)$, tak ani v klinické úspěšnosti $(p=0,5459)$.

Závěr: Nebyl nalezen signifikantní rozdíl mezi maturogenezí a apexifikací $\mathrm{Ca}(\mathrm{OH}){ }_{2}$ v klinické úspěšnosti a rentgenologické změně délky kořene. Signifikantní rozdíl ale byl ve změně rentgenologického povrchu kořene, jenž je u maturogeneze větší než u apexifikace $\mathrm{Ca}(\mathrm{OH})$.

Klíčová slova: maturogeneze - revaskularizace - apexifikace - stálý zub s nedokončeným vývojem 


\section{SUMMARY}

Introduction and aim: The endodontic treatment of necrotic immature permanent teeth is one of the most demanding intervention in the field of endodontics. In the last two decades there was an emerging evidence supporting the use of regenerative medicine concepts which aims to regenerate pulpdentinal organ. The aim of our study was to compare clinical success rate and change in radiological root area and radiological length between $\mathrm{Ca}(\mathrm{OH})_{2}$, apexification and maturogenesis.

Methods: Data of patients treated between years 2011 and 2015 at Institute of Dentistry and Oral Sciences in Olomouc who were younger than 16 years and simultaneously underwent endodontic treatment of immature permanent tooth were collected. From total of 54 patients, 17 were chosen according to designated criteria. Nine patients were treated by $\mathrm{Ca}(\mathrm{OH})$, apexification and 8 by maturogenesis. In the scope of follow-up, the control X-rays were taken and clinical examination was performed. The mathematical correction of control X-rays was carried out and percentual change in radiological root area and radiological length in comparison to diagnostic X-ray were determined. After assessment of normality of collected data with Wilk-Shapiro test, the null hypothesis was examined by student t-test and Wilcoxon signed-rank/rank-sum tests. The clinical outcome was tested by Fisher factorial test.

Results: There was significant difference in comparison of change in radiological root area among teeth treated with $\mathrm{Ca}(\mathrm{OH})_{2}$ apexification and maturogenesis $(\mathrm{p}=0.0041)$. The average change in radiological root area was $16 \%$ in cases treated with maturogenesis and $5.9 \%$ in cases treated with $\mathrm{Ca}(\mathrm{OH})_{2}$ apexification. No statistically significant differences were found in radiological length change $(p=0.939)$ and clinical success rate $(p=0.5459)$.

Conclusion: According to our data there were no significant differences between maturogensis and $\mathrm{Ca}(\mathrm{OH})_{2}$ apexification in clinical success rates and change of radiological lengths. Significant difference was observed in the change of radiological root, which was higher in cases treated by maturogenesis. Keywords: maturogenesis - revascularization - apexification - immature tooth

Čes. Stomat., roč. 117, 2017, č. 3, s. 52-59

\section{ÚVOD}

V endodoncii není mnoho složitějších klinických situací, než je terapie nekrotických stálých zubů s neukončeným vývojem. I při remisi příznaků jako výsledku klasických terapeutických modalit, jako je apexifikace pomocí hydroxidu vápenatého $-\mathrm{Ca}(\mathrm{OH})_{2}$ či ortográdní plnění pomocí moderních kalcium silikátových cementũ, zůstává dlouhodobá prognóza zubu spíše neuspokojivá. To je dáno velmi tenkými stěnami kořene, které jsou fragilní a mnohem snáze u nich může dojít $\mathrm{k}$ fraktuře.

V posledních dvou desetiletích došlo $\mathrm{k}$ výraznému pokroku v oblasti tkáňového inženýrství a rozšíření znalostí biologie zubní dřeně vedoucích $\mathrm{k}$ vytvoření strategií, jejichž cílem je formace nové vitální tkáně uvnitř kořenového systému. Tato nová tkáň je schopna produkovat tvrdé tkáně, a tím, kromě ztluštění stěny kořene, umožňuje i pokračování v jeho vývoji.

Je nutné zmínit, že pokud dojde ke ztrátě stálého zubu s neukončeným vývojem, a to zvláště ve frontálním úseku, je následná estetická rehabilitace pacienta velmi časově i finančně náročná a vyžaduje komplexní interdisciplinární přístup. Následný výsledek může být i přesto kompromisní. Z tohoto pohledu je zlepšení dlouhodobé prognózy takto postižených zubư velmi žádoucí.

\section{Výběr pacientů}

Do studie byli zařazeni pacienti s kompletní zdravotnickou dokumentací, kteří podstoupili endodontické ošetření stálých zubů s neukončeným vývojem na Klinice zubního lékařství v letech 2011-2015 a zároveň splňovali následující podmínky:

- měli stálý zub s nekrotickou dření a nedokončeným vývojem kořene s periapikálním nálezem nebo bez něj,

- byli ošetřeni apexifikací $\mathrm{Ca}(\mathrm{OH})_{2}$ nebo maturogenezí.

Naopak vyřazeni ze studie byli pacienti, u nichž:

- byly patrné známky zevní resorpce,

- došlo k selhání terapie v kratší době než šest měsíců od počátku terapie,

- v rámci postendodontického ošetření byla nutná protetická rekonstrukce klinické korunky,

- nebyly dostupné diagnostické snímky, snímky po ukončení terapie a kontrolní snímky minimálně jeden rok po ukončení terapie $v$ př́ipadě apexifikace,

- nebo šest měsíců v případě maturogeneze,

- byli ve vyšším věku než 16 let,

- nebylo možné provést matematickou korekci snímků. 
ČESKÁ STOMATOLOGIE ročník 117, 2017,3 , s. $52-59$
Záznamy obsahovaly informace o pohlaví, věku, lokalizaci zubu, klinických příznacích a symptomech, př́tomnosti periapikálního nálezu, radiologické délce kořene, rentgenologickém povrchu kořene a o délce sledování. $Z$ celkového počtu 54 pacientů bylo vyřazeno 12 pacientů, kteří byli ošetřeni apikální kalcium silikátovou zátkou, 15 pacientů ošetřených apexifikací $\mathrm{Ca}(\mathrm{OH})_{2}$, kteří nedodrželi následné kontroly, osm pacientù ošetřených apexifikací $\mathrm{Ca}(\mathrm{OH})_{2}$, u kterých nebylo možno provést geometrickou korekci snímkư, jeden pacient ošetřený maturogenezí, u kterého se objevily známky zevní resorpce kořene, a jeden pacient ošetřený maturogenezí, kde došlo k selhání terapie dva měsíce po provedení zákroku. Dohromady bylo zahrnuto do studie devět pacientů ošetřených apexifikací $\mathrm{Ca}(\mathrm{OH})_{2}$ (s 11 ošetřenými zuby) (tab. 1) a osm pacientů ošetřených maturogenezí (s osmi ošetřenými zuby) (tab. 2).

$\mathrm{K}$ apexifikaci $\mathrm{Ca}(\mathrm{OH})_{2}$ byly použity konvenční výplachy $1 \%$ chlornanem sodným a dlouhodobou aplikací $\mathrm{Ca}(\mathrm{OH})_{2}$ po průměrnou dobu 26,5 měsíce. Maturogeneze byla uskutečněna podle doporučení Americké asociace endodontistů (AAE) s využitím $\mathrm{Ca}(\mathrm{OH})_{2}[4]$.

\section{Matematická korekce rentgenových snímků}

Pro korekci odchylek projekcí jsme zvolili postup matematické korekce podle Boseho [3]. Diagnostický snímek, popřípadě snímek ihned po ukončení terapie byl spolu s kontrolním snímkem uložen ve formátu JPEC a převeden do programu Image J (verze 1.49, National Institutes of Health, Bethesda, MD, USA), jenž slouží k měření a ukládání výsledkũ. K matematické minimalizaci možných rozdílů mezi diagnostickými a kontrolními snímky, které mohly být způsobeny rozdílnými projekcemi, byla využita plug-in aplikace TurboReg (Biomedical Imaging Group, Swiss Federal Institute of Technology, Lausanne, Švýcarsko). Algoritmus plug-in TurboReg realizuje slučovací geometrickou transformaci (angl. affine transformation) u dvou rentgenových snímků, aby projekce byly srovnatelné na obou snímcích. Podle dříve popsané metodiky [3, 9] byl vybrán diagnostický snímek nebo snímek tzv. zdrojový, pořízený ihned po ukončení terapie, který se nejvíce blížil izometrické a ortoradiální projekci. Kontrolní snímek, jenž má být upraven, nazýváme cílový snímek. Na obou snímcích - jak zdrojovém, tak cílovém - označíme tři referenční body, které nám vymezí referenční

Tab. 1 Pacienti zahrnutí do studie, kteří byli ošetřeni apexifikací $\mathrm{Ca}(\mathrm{OH})_{2}$

\begin{tabular}{|c|c|c|c|c|c|c|}
\hline Pacient & Věk & Zub & Etiologie & Př́tomnost PA & Follow-up (měs.) & Délka působení $\mathrm{Ca}(\mathrm{OH})_{2}$ (měs.) \\
\hline Pacient 1 & 11 & 11 & úraz & ano & 16 & 25 \\
\hline Pacient 1 & 11 & 21 & úraz & ano & 16 & 25 \\
\hline Pacient 2 & 13 & 11 & úraz & ano & 37 & 12 \\
\hline Pacient 3 & 9 & 21 & úraz & ano & 37 & 40 \\
\hline Pacient 4 & 16 & 11 & kaz & ano & 25 & 22 \\
\hline Pacient 4 & 16 & 21 & kaz & ano & 25 & 22 \\
\hline Pacient 5 & 7 & 11 & úraz & ano & 7 & 28 \\
\hline Pacient 6 & 13 & 21 & úraz & ano & 14 & 50 \\
\hline Pacient 7 & 9 & 41 & úraz & ano & 14 & 20 \\
\hline Pacient 8 & 8 & 19 & autotransplantace & ne & 33 & 21 \\
\hline Pacient 9 & 8 & 11 & úraz & ano & 9 & 47 \\
\hline
\end{tabular}

Tab. 2 Pacienti zahrnutí do studie, kteří byli ošetřeni maturogenezí

\begin{tabular}{|l|l|l|l|l|l|}
\hline Pacient & Zub & Vĕk & Etiologie & Prítomnost PA & Follow-up \\
\hline Pacient 1 & 21 & 9 & úraz & ano & 12 \\
\hline Pacient 2 & 21 & 8 & úraz & ne & 20 \\
\hline Pacient 3 & 21 & 7 & úraz & ano & 14 \\
\hline Pacient 4 & 21 & 8 & úraz & ano & 12 \\
\hline Pacient 5 & 11 & 7 & úraz & ano & 6 \\
\hline Pacient 6 & 22 & 12 & dens in dente & & 12 \\
\hline Pacient 7 & 11 & 8 & úraz & ano & 12 \\
\hline Pacient 8 & 11 & 9 & úraz & ne & 18 \\
\hline
\end{tabular}



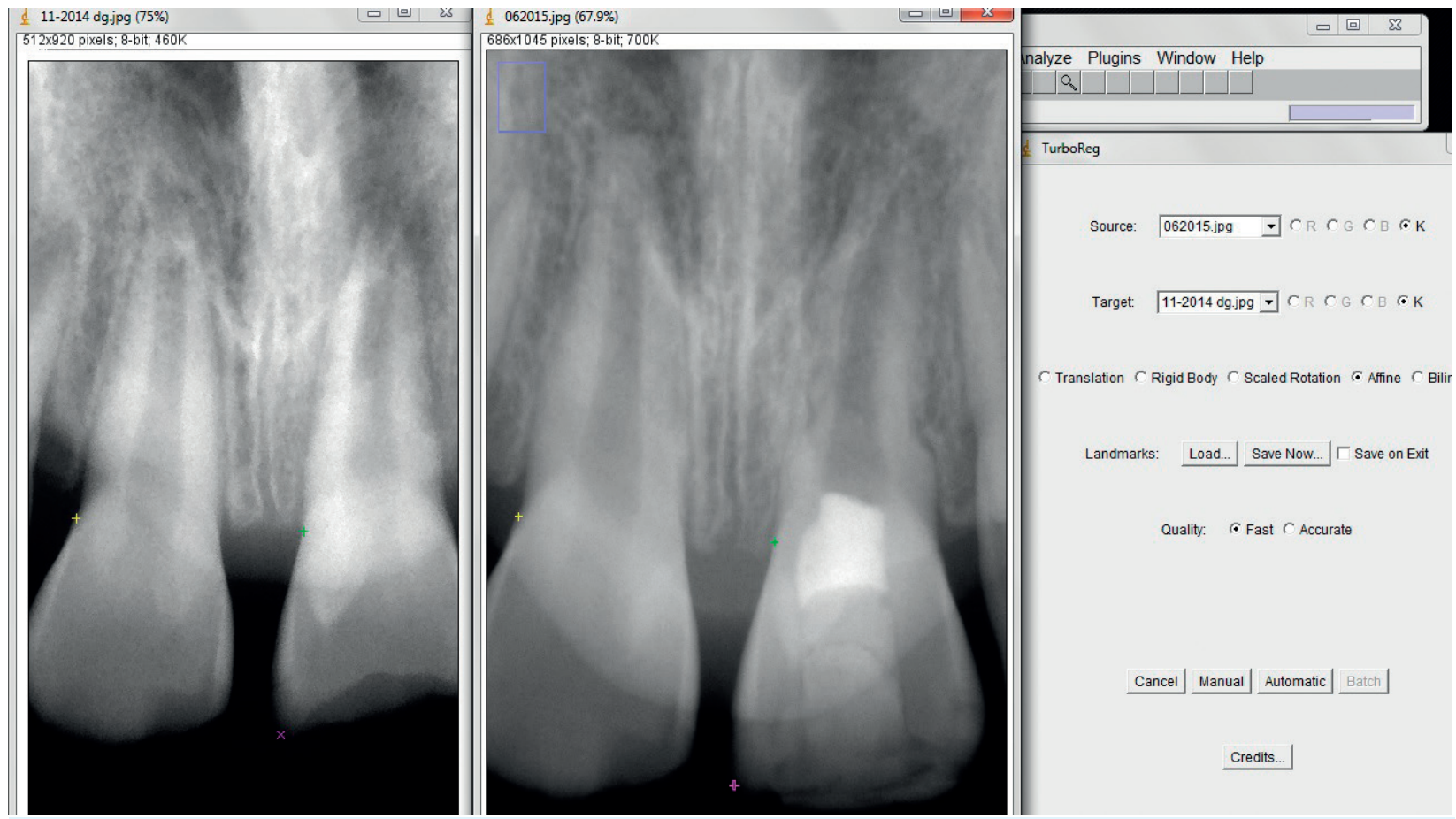

plochu. Referenčními body mohou být pouze ty, které jsou jednoduše určitelné a $v$ čase neměnné. V našem případě se jednalo zvláště o cementosklovinnou hranici, okraje výplní a apexy zubů s již ukončeným vývojem. Zvláštní zřetel byl brán na to, aby byly body vzdáleny od sebe co nejvíce a aby se pozice referenčních bodů $\mathrm{v}$ čase neměnila (např. neprořezané zuby nebo apexy zubů s ještě neukončeným vývojem). U všech snímků bylo možné najít vhodné referenční body a byl vybrán automatický mód (angl. automatic mode) pro korekci snímků, aby byla eliminována možná chyba hodnotícího. Kompletní postup geometrické korekce je zobrazen na obrazové dokumentaci (obr. 1).

\section{Stanovení rentgenologického přírůstku tvrdých zubních tkání}

Pro hodnocení zisku tvrdých zubních tkání se zpočátku využívala technika podle Boseho a kol. [3], kteří měřili tloušt́ku stěny kořene v přechodu mezi střední a apikální třetinou. Problematické na této technice je měření pouze $v$ jednom místě, které je navíc obtížně určitelné, pokud dochází k pokračování růstu kořene do délky. Nevýhody této techniky do velké míry eliminuje technika radiologického povrchu zubu podle Flakea a kol. (angl. radiological root area, RRA) [5]. Tato technika prokázala vysokou míru shody mezi hodnotiteli, takže byl vyloučen vliv hodnotitele na měření [5].

\section{Radiologický povrch kořene byl vypočten podle} vzorce:

RRA = RPCK - RPKK,

kde hodnoty RPCK (radiologický povrch celého kořene) a RPKK (radiologický povrch kořenového kanálku) byly změřeny pomocí funkce „polygon“ programu Image J (verze 1.49, National Institutes of Health, Bethesda, MD, USA). Touto funkcí se ohraničil pomocí co největšího počtu bodů povrch celého kořene, respektive povrch kořenového kanálku (obr. 2). Po vnitřní kalibraci hodnotitele byl radiologický povrch kořene stanoven pětkrát na snímcích po slučovací geometrické korekci $\mathrm{a} z$ těchto hodnot byla vytvořena průměrná hodnota. Předchozí práce dokazují vysokou míru spolehlivosti a reprodukovatelnosti [5]. Vzhledem k různému rozlišení snímků nebylo možné využít absolutní hodnoty, a tak jsme přistoupili k hodnocení relativních hodnoty - tj. procentuální změně oproti stavu na počátku terapie.

\section{Stanovení změny délky kořene}

Pro stanovení změny délky kořene jsme využili techniku, již popsali Bose a kol. [3]. Využili jsme funkci „straight line“ programu Image J (verze 1.49, National Institutes of Health, Bethesda, MD, USA). Spojením cementosklovinné hranice a radiologického apexu zubu jsme získali „radiologickou délku 


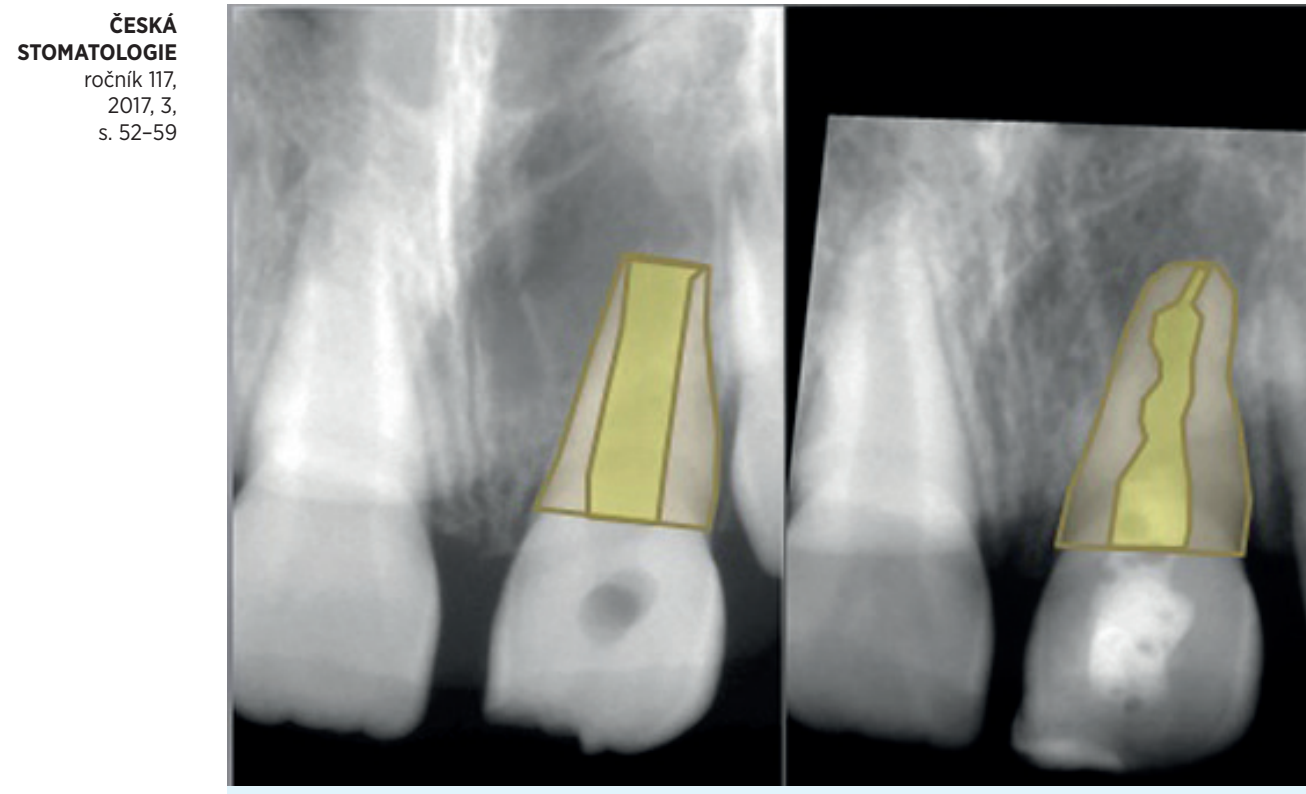

Obr. 2 Diagnostický snímek a upravený kontrolní snímek. Na obou je vyznačen rentgenologický povrch kořene (béžová barva). přistoupili k hodnocení hodnoty relativní - tj. procentuální změny oproti stavu na počátku.

\section{Klinická úspěšnost}

Klinické a radiologické kontroly se realizovaly v tř́měsíčních intervalech v prvním roce a následně každých šest měsíců. $V$ průběhu každé kontroly jsme cíleně klinicky vyšetřili, zda je zub asymptomatický; poté jsme zhotovili kontrolní snímek. Zub byl vyhodnocen jako klinicky klidný $v$ př́padě, pokud nebylo přítomno periapikální projasnění na kontrolním snímku a zub byl při klinickém vyšetření asymptomatický. Všechny změřené hodnoty jsou v přiložených tabulkách pro apexifikaci $\mathrm{Ca}(\mathrm{OH})_{2}$ (tab. 3) a maturogenezi (tab. 4). kořene" (obr. 3). Po vnitřní kalibraci hodnotitele jsme toto měření opakovali pětkrát. Hodnoty byly po týdnu opětovně změřeny, aby byla zajištěna reprodukovatelnost měření. Jako závěrečnou radiologickou délku kořene jsme brali průměrnou hodnotu ze všech naměřených hodnot pro daný rentgenový snímek. Vzhledem k různému rozlišení snímků nebylo možné využít absolutní hodnoty, a tak jsme

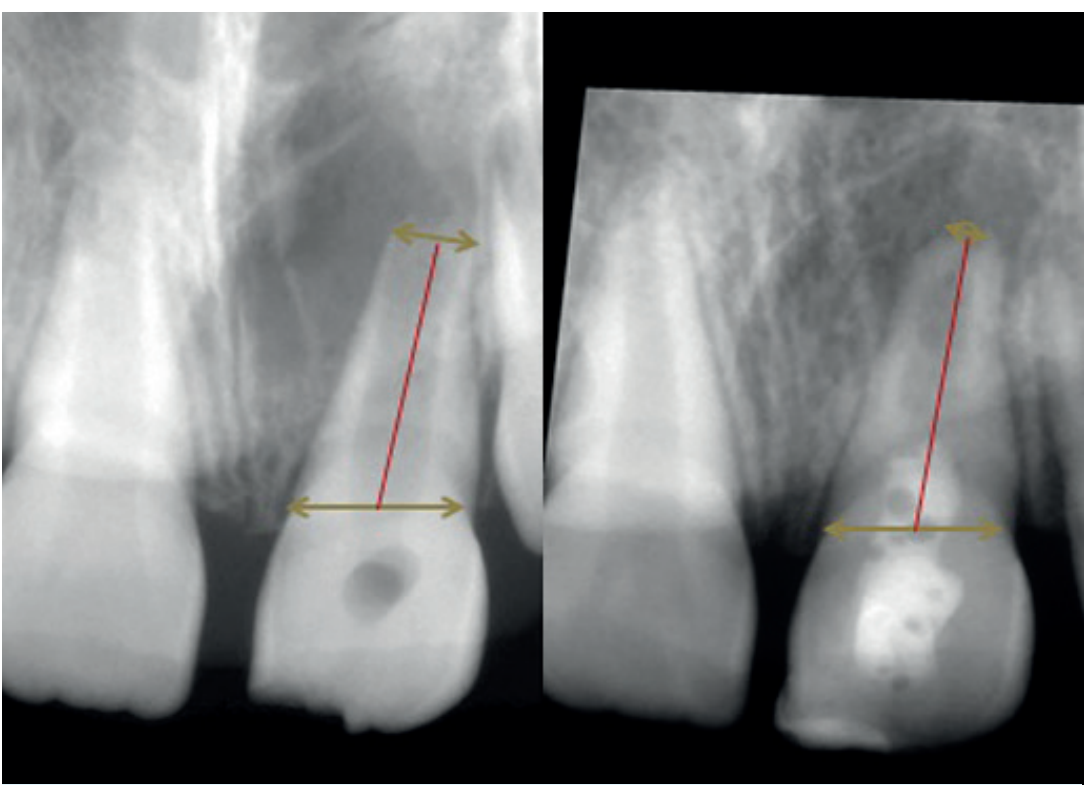

Obr. 3 Diagnostický snímek a upravený kontrolní snímek. Na obou je vyznačena radiologická délka kořene.

\section{VÝSLEDKY}

\section{Stanovení rentgenologického povrchu kořene}

\section{Maturogeneze}

Normalitu hodnot nezamítáme (ShapirůvWilkův test; $p=0,2138$ ). Nulovou hypotézu, že při ošetření maturogenezí se rentgenologický povrch kořene po ošetření nemění, zkoumáme Studentovým t-testem. Nulovou hypotézu zamítáme $(\mathrm{p}=0,007)$. Nárůst rentgenologického povrchu kořene je statisticky významný a činí $16 \%$ (průměrná hodnota změny RRA při maturogenezi).

\section{Apexifikace $\mathrm{Ca}(\mathrm{OH})_{2}$}

Normalitu hodnot zamítáme (Shapirův-Wilkův test; $\mathrm{p}$ = $0,0012)$. Nulovou hypotézu, že při ošetření apexifikací $\mathrm{Ca}(\mathrm{OH})_{2}$ se rentgenologický povrch kořene po ošetření nemění, zkoumáme jednovýběrovým Wilcoxonovým testem. Nulovou hypotézu nezamítáme $(p=0,5771)$. Změna rentgenologického povrchu kořene není statisticky významná a činí 5,9 \% (průměrná hodnota změny RRA při apexifikaci $\mathrm{Ca}(\mathrm{OH})_{2}$ ). 
Tab. 3 Naměřené hodnoty radiologické délky kořene, radiologického povrchu kořene a jejich změn u zubů ošetřených apexifikací Ca(OH),

\begin{tabular}{|c|c|c|c|c|c|c|c|}
\hline Pacient & Klinicky klidný & Počáteční RRA & Konečná RRA & \% změna RRA & Počáteční délka & Konečná délka & \% změna délky \\
\hline Pacient 1 & ano & 52671,3 & 50048 & $-5,2 \%$ & 468,1 & 462,8 & $-1,1 \%$ \\
\hline Pacient 1 & ano & 45893,7 & 42104,3 & $-9,0 \%$ & 408,1 & 414,1 & $1,4 \%$ \\
\hline Pacient 2 & ano & 37478 & 35609,3 & $-5,2 \%$ & 416,8 & 420,6 & $0,9 \%$ \\
\hline Pacient 3 & ano & 93760,3 & 88838 & $-5,5 \%$ & 656,7 & 659,1 & $0,4 \%$ \\
\hline Pacient 4 & ano & 42470 & 49474,3 & $14,2 \%$ & 495,4 & 507,4 & $2,4 \%$ \\
\hline Pacient 4 & ano & 52618,3 & 57243 & $8,1 \%$ & 523,5 & 558,6 & $6,3 \%$ \\
\hline Pacient 5 & ano & 37451,3 & 57775,3 & $35,2 \%$ & 421,2 & 497,7 & $15,4 \%$ \\
\hline Pacient 6 & ano & 43870 & 44930,3 & $2,4 \%$ & 451,3 & 469,2 & $3,8 \%$ \\
\hline Pacient 7 & ano & 33799,3 & 32312 & $-4,6 \%$ & 549,7 & 559,7 & $1,8 \%$ \\
\hline Pacient 8 & ano & 41542,3 & 46741,3 & $11,1 \%$ & 514,7 & 521,8 & $1,4 \%$ \\
\hline Pacient 9 & ne (ex) & 17397 & 17184 & $-1,2 \%$ & 272,2 & 280,6 & $3,0 \%$ \\
\hline
\end{tabular}

Tab. 4 Naměřené hodnoty radiologické délky kořene, radiologického povrchu kořene a jejich změn u zubů ošetřených maturogenezí

\begin{tabular}{|l|c|c|c|c|c|c|c|}
\hline Pacient & $\begin{array}{c}\text { Klinicky } \\
\text { klidný }\end{array}$ & $\begin{array}{c}\text { Počáteční } \\
\text { RRA }\end{array}$ & Konečná RRA & \% změna RRA & $\begin{array}{c}\text { Počáteční } \\
\text { délka }\end{array}$ & $\begin{array}{c}\text { Konečná } \\
\text { délka }\end{array}$ & $\begin{array}{c}\text { \% změna } \\
\text { délky }\end{array}$ \\
\hline Pacient 1 & ano & 15531 & 19455,3 & $20,2 \%$ & 194,2 & 229,3 & $15,3 \%$ \\
\hline Pacient 2 & ano & 107109 & 111377 & $3,8 \%$ & 738,9 & 746,2 & $1,0 \%$ \\
\hline Pacient 3 & ne & 20673,7 & 29213 & $29,2 \%$ & 356,3 & 361,4 & $1,4 \%$ \\
\hline Pacient 4 & ano & 7268,3 & 7980,7 & $8,9 \%$ & 175,4 & 185,4 & $5,4 \%$ \\
\hline Pacient 5 & ne & 22198,3 & 24588,3 & $9,7 \%$ & 300 & 341 & $12,0 \%$ \\
\hline Pacient 6 & ano & 11857,1 & 12506 & $5,2 \%$ & 256 & 261,5 & $2,1 \%$ \\
\hline Pacient 7 & ano & 23649,3 & 27747,7 & $14,8 \%$ & 385 & 381,7 & $-0,9 \%$ \\
\hline Pacient 8 & ano & 78748 & 91617 & $14,0 \%$ & 758,1 & 765,7 & $1,0 \%$ \\
\hline
\end{tabular}

\section{Rozdíly mezi léčebnými modalitami}

Nulovou hypotézu, že není rozdíl mezi maturogenezí a apexifikací $\mathrm{Ca}(\mathrm{OH})_{2}$, zkoumáme neparametrickým dvouvýběrovým Wilcoxonovým testem ( $p=0,041)$. Rozdíl mezi léčebnými modalitami, pokud jde o zvětšení rentgenologického povrchu kořene, je významný ve prospěch maturogeneze (graf 1).

\section{Stanovení změny rentgenolo- gické délky kořene}

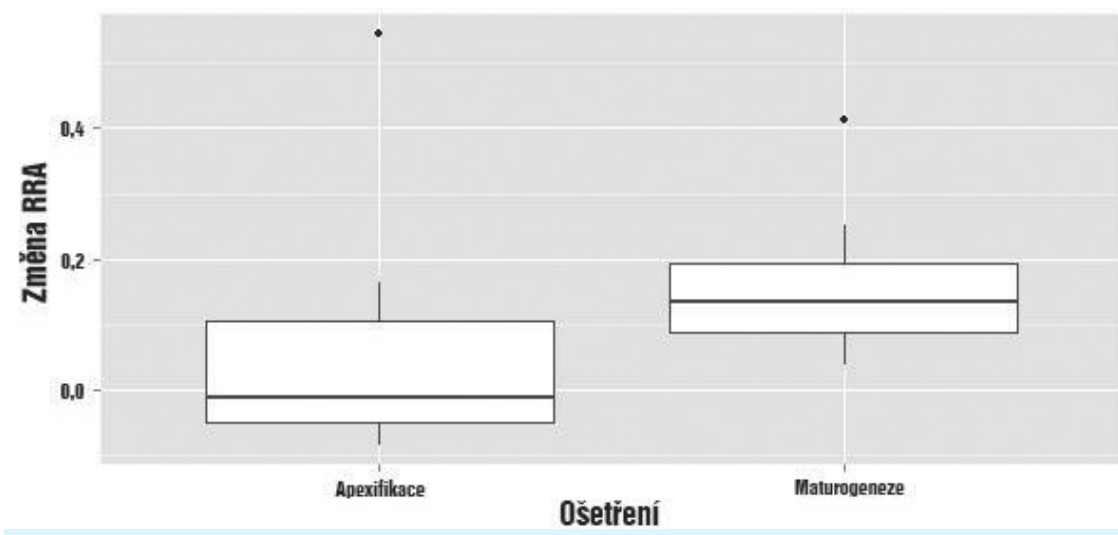

Graf 1 Grafické znázornění procentuální změny rentgenologického povrchu kořene v závislosti na zvolené metodě léčby

\section{Maturogeneze}

Normalitu hodnot změny rentgenologické délky zamítáme (Shapirův-Wilkův test; $\mathrm{p}=0,02872$ ). Nulovou hypotézu, že rentgenologická délka se po ošetření maturogenezí nemění, zkoumáme jednovýběrovým Wilcoxonovým testem. Nulovou hypotézu zamítáme ( $\mathrm{p}=0,01563)$. Změna rentgenologické délky po ošetření je statisticky významná, a to v průměru o $5,3 \%$.

\section{Apexifikace $\mathrm{Ca}(\mathrm{OH})_{2}$}

Normalitu hodnot zamítáme (Shapirův-Wilkův test; $p=0,00047)$. Nulovou hypotézu, že rentge- 


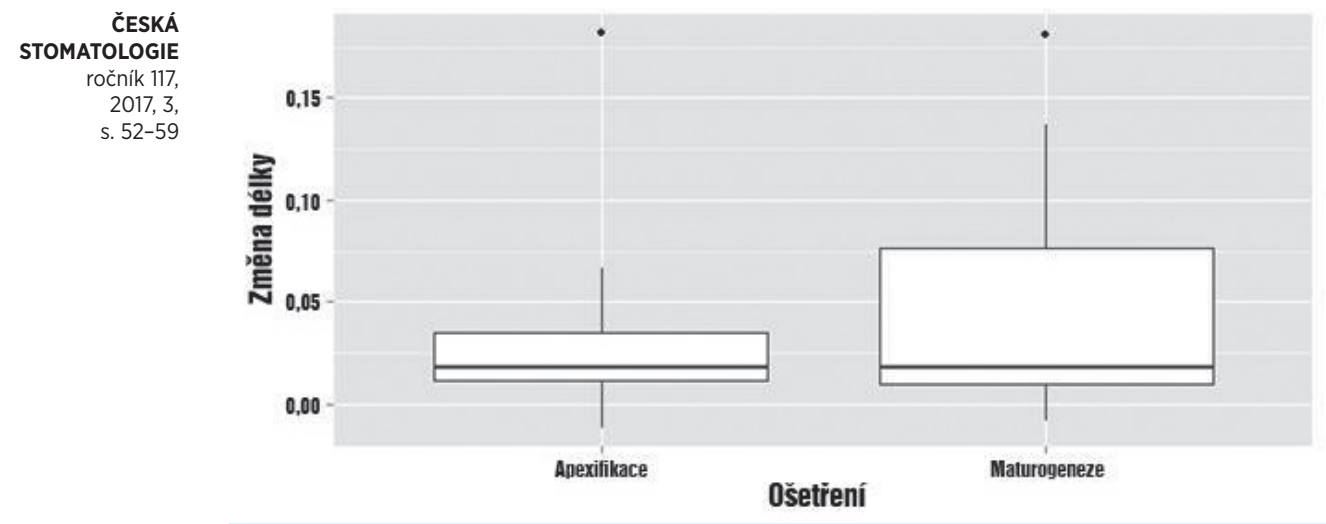

Graf 2 Grafické znázornění procentuální změny rentgenologické délky kořene v závislosti na zvolené metodě léčby sledku jeho nízké koncentrace nižší. To může vést pouze ke krátkodobému snížení množství bakterií a selhání terapie za delší časový úsek. Nicméně i toto krátkodobé snížení množství bakterií mưže vytvořit podmínky vhodné pro tvorbu mineralizované tkáně na povrchu kořene, a tedy mưže dojít k naplnění sekundárních cílư terapie, i když primární cíle splněny nebudou [10]. Tomu odpovídá i zvýšené riziko komplikací u maturogenezí [1] .

Statisticky signifikantní je

nologická délka se po ošetření $\mathrm{Ca}(\mathrm{OH})_{2}$ nemění, zkoumáme jednovýběrovým Wilcoxonovým testem. Nulovou hypotézu zamítáme ( $\mathrm{p}=0,004883)$. Změna rentgenologické délky po ošetření je statisticky významná, a to $\mathrm{v}$ průměru o $3,56 \%$.

\section{Rozdíly mezi léčebnými modalitami}

Nulovou hypotézu, že není rozdíl mezi maturogenezí a apexifikací $\mathrm{Ca}(\mathrm{OH})$, zkoumáme neparametrickým dvouvýběrovým Wilcoxonovým testem. Nulovou hypotézu nezamítáme $(\mathrm{p}=0,939)$. Rozdíly ve změně délky kořene mezi léčebnými modalitami nejsou statisticky signifikantní (graf 2).

\section{Klinická úspěšnost}

Porovnání klinické úspěšnosti obou léčebných modalit jsme vzhledem k malé četnosti hodnot zkoumali neparametrickým Fisherovým faktoriálovým testem. Nulovou hypotézu, že mezi úspěšnostmi jednotlivých léčebných modalit není rozdíl, nezamítáme ( $\mathrm{p}=0,5459)$.

\section{DISKUSE}

Klinická úspěšnost obou léčebných postupů je podle našich výsledků shodná. Je ale nutné zdůraznit, že vzorek pacientů je relativně limitovaný, což je dáno obecně malou incidencí případů stálých zubư s neukončeným vývojem a nekrotickou dření. Z našeho pohledu je nezbytné zdưraznit, že u silně infikovaného systému kořenových kanálků je nutné předpokládat přítomnost vysoce vyzrálého biofilmu. V tomto případě je zvýšené riziko, že výplachový protokol podle AAE bude méně účinný. Je to dáno tím, že mechanické odstranění biofilmu v průběhu opracování kořenového kanálku je eliminováno úplně a proteolytické pưsobení chlornanu sodného na extracelulární matrix biofilmu je v dů- přírůstek rentgenologického povrchu kořene a potažmo šířky kořene. Toto zjištění odpovídá předchozím studiím, které se touto problematikou zabývaly. Námi změřená změna rentgenologického povrchu kořene 16,3 \% se dá porovnat jenom s jednou studií [2]. Pouze orientačně se dají využít studie, které měřily šiřku kořene jen $v$ jednom daném místě [3]. Některé studie však neprokázaly signifikantní rozdíl mezi maturogenezí a apexifikací, z hlediska změn rentgenologického povrchu kořene [1]. Obecně je charakter tkáně spíše reparativní než regenerativní, a pokud jde o množství a charakter tkáně, jsou nepředvídatelné.

Na rozdíl od přírůstku rentgenologického povrchu kořene není délkový přírůstek statisticky signifikantní. Jak bylo prokázáno Bosem a kol., při aplikaci $\mathrm{Ca}(\mathrm{OH})_{2}$ pouze do koronální poloviny při apexifikaci $\mathrm{Ca}(\mathrm{OH})_{2}$ dochází k signifikantnímu prodloužení kořene oproti aplikaci $\mathrm{Ca}(\mathrm{OH})_{2}$ do celého systému kořenových kanálků [3]. Mưžeme tedy předpokládat, že podstatnou roli na prodloužení kořene do délky hraje Hertwigova epiteliální pochva. Tomuto zjištění odpovídají i další studie, kde nebylo prodloužení signifikantní $[1,7]$. Existují ale studie, které signifikantní rozdíl v délce kořene prokázaly [3, 6, 8]. Ve všech těchto studiích byla maturogeneze porovnávána s apexifikací, at' už pomocí $\mathrm{Ca}(\mathrm{OH})_{2}$, který se aplikoval do celého kořenového systému, nebo MTA (mineral trioxide aggregate).

\section{ZÁVĔR}

Podle našich výsledků není mezi apexifikací pomocí $\mathrm{Ca}(\mathrm{OH})_{2}$ a maturogenezí rozdíl v klinické úspěšnosti a rentgenologické změně délky kořene. Signifikantní rozdíl je ale ve změně rentgenologického povrchu kořene, jež je u maturogeneze větší než $\mathrm{u}$ apexifikace $\mathrm{Ca}(\mathrm{OH})_{2}$. 


\section{LITERATURA}

1. Alobaid, A. S., Cortes, L. M., Lo, J., Nguyen, T. T., et al.: Radiographic and clinical outcomes of the treatment of immature permanent teeth by revascularization or apexification: a pilot retrospective cohort study. J. Endod., roč. 40, 2014, č. 8, s. 1063-1070.

2. Bezgin, T., Yilmaz, A. D., Celik, B. N., Kolsuz, M. E., et al.: Efficacy of platelet-rich plasma as a scaffold in regenerative endodontic treatment. J. Endod., roč. 41, 2015, č. 1, s. 36-44.

3. Bose, R., Nummikoski, P., Hargreaves, P.: A retrospective evaluation of radiographic outcomes in immature teeth with necrotic root canal systems treated with regenerative endodontic procedures. J. Endod., roč. 35, 2009, č. 10, s. 1343-1349.

4. American Association of Endodontists: $A A E$ clinical considerations for a regenerative procedure 2015. In., 2015. dostupné na https://www.aae.org/uploadedfiles/publications_and_research/research/currentregenerativeendodonticconsiderations.pdf.

5. Flake, N. M., Gibbs, J. L., Diogenes, A., Hargreaves, K. M., et al.: A standardized novel method to measure radiographic root changes after endodontic therapy in immature teeth. J. Endod., roč. 40, 2014, č. 1, s. 46-50.

6. Jeeruphan, T., Jantarat, J., Yanpiset, K., Suwannapan, L., et al.: Mahidol study 1: comparison of radiographic and survival outcomes of immature teeth treated with either regenerative endodontic or apexification methods: a retrospective study. J. Endod., roč. 38, 2012, č. 10, s. 1330-1336.

7. Kahler, B., Mistry, S., Moule, A., Ringsmuth, A. K., et al.: Revascularization outcomes: a prospective analysis of 16 consecutive cases. J. Endod., roč. 40, 2014, č. 3, s. 333-338.

8. Nagy, M. M., Tawfik, H. E., Hashem, A. A., Abu-Seida, V.: Regenerative potential of immature permanent teeth with necrotic pulps after different regenerative protocols. J. Endod., roč. 40, 2014, č. 2, s. 192-198.

9. Webber, R. L., Ruttiman, U. E., Groenhuis, R. A.: Computer correction of projective distortions in dental radiographs. J. Dent. Res., roč. 63, 1984, č., 8, s. 1032-1036.

10. Žižka, R., Buchta, T., Voborná, I., Harvan, L., et al.: Root maturation in teeth treated by unsuccessful revitalization: 2 case reports. J. Endod., roč. 42, 2016, č. 5, s. 724-729.
MDDr. Radovan Žižka

Zahradní 380/10

77000 Olomouc

e-mail: radovan.zizka@upol.cz
ČESKÁ

STOMATOLOGIE

ročník 117,

2017,3 ,

s. $52-59$ 